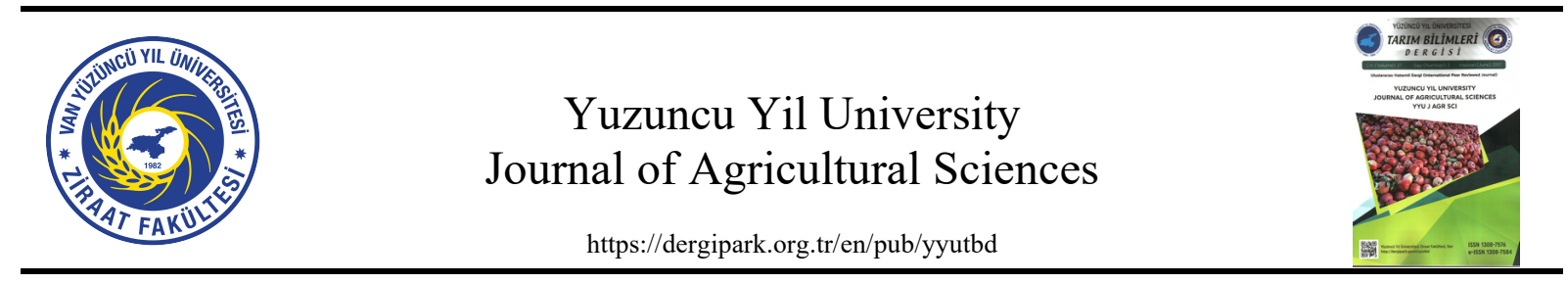

Research Article

\title{
Influence of Groundnut Waste as Substrate and Host Plant on Inoculum Production of Endophytic Mycorrhiza for Large Scale Agricultural Application
}

\author{
Ashish KUMAR $^{* 1}$, Ashok AGGARWAL ${ }^{2}$, Navnita SHARMA ${ }^{3}$, Anil GUPTA ${ }^{4}$ \\ 1,2,3 Department of Botany, Kurukshetra University, Kurukshetra, India \\ ${ }^{4}$ Botany Faculty, Institute of Integrated and Honors Studies, Kurukshetra University, Kurukshetra, India \\ ${ }^{1}$ https://orcid.org/0000-0001-9189-940X ${ }^{2}$ https://orcid.org/0000-0002-5333-9097 ${ }^{3} \mathrm{https}: / /$ orcid.org/0000-0001-8831-7456 \\ ${ }^{4} \mathrm{https}: / /$ orcid.org/0000-0002-6088-1466 \\ *Corresponding author e-mail:ashish2020@kuk.ac.in
}

\section{Article Info}

Received: 16.04 .2021

Accepted: 14.07.2021

Online Published 15.09.2021

DOI: $10.29133 /$ yyutbd.910233

Keywords

Arbuscular mycorrhizal

fungi,

Groundnut waste,

Root colonization

\begin{abstract}
A pot culture experiment was conducted to study the effect of soil amendment with different forms of groundnut waste on spore population and root infection of indigenous Arbuscular Mycorrhizal fungal species i.e. Glomus mosseae under polyhouse conditions. Two angiospermic plant species viz. sorghum and sesame were also examined for mycorrhization potential in the study. Observations were made for percent root colonization, spore density of AM fungi and the effectiveness of AM fungi on the shoot and root biomass of both host plants. The results indicated that AM fungal spore population and colonization levels were substantially enhanced by the application of compost groundnut waste as a substrate over dry groundnut waste. Among growth parameters, plant height, root length and plant biomass were recorded more in sorghum than sesame. On the whole, mycorrhization was reported the highest with $75 \mathrm{~g} /$ pot concentration of waste. Also, sorghum appeared to be a better host than sesame.
\end{abstract}

\section{Büyük Ölçekli Tarımsal Uygulama İçin Endofiz Mikorrhizasının İnokülum Üretimi Üzerinde Substrat ve Konak Bitki Olarak Yer Fistığı Atıklarının Etkisi}

\section{Makale Bilgileri}

Geliș: 16.04 .2021

Kabul: 14.07.2021

Online Yayınlanma 15.09.2021

DOI: $10.29133 /$ yyutbd.910233

\section{Anahtar Kelimeler}

Arbuscular mikorzal funguslar,

Groundnut atıkları, Kök kolonizasyonu
Öz: Farklı yerfıstığı atığı formları ile ıslah edilen toprakların, sera koşullarında yerli Arbuscular Mycorrhizal Fungus türlerinin, yani Glomus mosseae'nin spor popülasyonu ve kök enfeksiyonu üzerindeki etkisini incelemek için bir saksı kültürü deneyi yapılmıştır. İki anjiyospermik bitki türü olan sorghum ve susam bitkileri de çalışmada mikoriza potansiyeli açısından incelenmiştir. Her iki konukçu bitkinin sürgün ve kök biyokütlesi üzerinde yüzde kök kolonizasyonu, AM funguslarının spor yoğunluğunu ve AM funguslarının etkinliğini tespit etmek için gözlemler yapılmıştır. Sonuçlar, kuru yerfıstığı atığı üzerine bir substrat olarak kompost yerfistığı atığının uygulanmasıyla AM fungus spor popülasyonunun ve kolonizasyon seviyelerinin önemli ölçüde arttığını göstermiştir. Büyüme parametreleri arasından bitki boyu, kök uzunluğu ve bitki biyokütlesi sorgum bitkisinde susama göre daha fazla kaydedilmiştir. Genel olarak, en yüksek mikorizamiktarı $75 \mathrm{~g} / \mathrm{saks}$ atık konsantrasyonunda tespit edildi. Ayrıca, sorgum bitkisinin susam bitkisinden daha iyi bir konukçu olduğu görülmüştür. 


\section{Introduction}

The productive improvement of plants through regular use of synthetic fertilizer is the most common habit among farmers because nutrient availability is an important yield determining factor. But the huge application of synthetic fertilizers leads to degradation of long term soil fertility, pollution and increased disease susceptibility in the plant (Eman et al., 2008). The use of soil microbes as bio-fertilizer with respect to sustainable agriculture is becoming increasingly urgent since the apposite management of these microbes could potentially decrease the dependency on synthetic fertilizers. Among different soil microbes used as biofertilizer, AM fungi (AMF) are most common due to their ubiquitous distribution and forming a symbiosis with the roots of nearly 80 percent of the plant community, played an important role in the restoration of soil fertility (Pacheco et al., 2021). These arbuscular mycorrhizal fungi are widely known to improve plant growth through stimulating nutritional uptake, water absorption, made infected plants healthier and tolerant to drought, salinity and pathogen attack by activation of different kinds of alleviating processes associated with stresses (Sharma et al., 2017; Kumar et al., 2020). To achieve the benefits, the main approach adopted is the introduction of AMF propagules i.e. rhizospheric soil having AMF spores and colonized root fragments into destined soil. Unfortunately, the obligate symbiotic nature of AMF does not let them flourish in pure cultures, distant from their host plants making it challenging to produce large scale AMF inoculums. Except for its nature, demand for pathogen-free inoculum with an increased shelf life is another factor that limits its application at the commercial level. In spite of the availability of different kinds of techniques intentionally meant for inoculum production of AM fungi, the traditional pot-culture method is one of the most commonly followed methods where the AMF spores are usually maintained and multiplied in combination with suitable host plant roots (Kadian et al., 2019).

Groundnut is the second most nutritious legume in the world after soya-bean known for its diverse uses including oil production, human consumption as food and also animal consumption in the forms like hay, silage and cake. Approximately, $97 \%$ of the global area is used for groundnut cultivation mainly in developing countries and that contributes 94\% of groundnut production (Prasad et al., 2009). One tone of groundnut yield produces approximately $35-40 \mathrm{~kg}$ shell waste, left after the extraction of groundnut seed from its pod. This is the abundant lingo-cellulosic waste product that has a very slow degradation rate under natural conditions (Zheng et al., 2013; Musekiwa et al., 2020). However, lingocellulosic agricultural wastes after crop harvest the usually left in unused form or burned which elevate the level of greenhouse gases in the atmosphere (Guzmán et al., 2015). Thus, new technologies have been adopted to maximise the use of agricultural waste products for meaningful purposes like integration of small fractions in animal feed, used in pulp production, bio-ethanol production and wastewater treatment. These wastes in their original or compost form and in definite proportion could be applied to the soil deliberately to assess their consequence on fauna and flora. Several workers have introduced waste substrates in addition to the soil-sand mixture to promote the AM fungal growth earlier (Tanwar et al., 2013; Kadian et al., 2018). In this series of investigations, groundnut wastes or groundnut shell waste may be a useful substrate as it contains cellulose (35.7\%), hemicelluloses (18.7\%), lignin (30.2\%) and has total nitrogen $0.87 \%$, total phosphorus content $1.87 \%$, total potassium $1.19 \%$, organic carbon $30.0 \%$ and $\mathrm{C} / \mathrm{N}$ ratio 34.5 (Torkashvand et al., 2015; Ramgopal et al., 2016).

Keeping in view, the concept of sustainability, obligate biotrophic nature and importance of AM fungi, production of agricultural waste and demand for AM inoculum, a systematic investigation was undertaken to assess the mass production of Glomus mosseae using sorghum and sesame as hosts and different form of groundnut waste as substrate. Moreover, the lack of external application of synthetic fertilizers to the soil and published reports concerning the use of groundnut waste as substrate for mass production of AM fungal inoculum made it different from earlier studies.

\section{Material and Methods}

\subsection{Study site and soil characterstics}

The experiment was performed under polyhouse conditions at the Botany Department, Kurukshetra University, Kurukshetra, Haryana, from September 2018 to January 2019. Soil used in this 
experiment consisted of sand $64.2 \%$, clay $3.90 \%$, silt $21.81 \%$, pH $6.8 \pm 0$, EC $0.25 \mathrm{dS} \mathrm{m}^{-1}$, organic carbon $0.40 \%$, nitrogen $0.042 \%$, phosphorous $0.017 \%$ and potassium $220 \mathrm{~kg} \mathrm{ha}^{-1}$.

\subsection{Experimental design}

The experiment was a $4 \times 2 \times 2$ factorial in a completely randomized design employing two types of hosts (sesame and sorghum) and four concentrations (without substrate (control), 50, 75, $\left.100 \mathrm{~g} \mathrm{pot}^{-1}\right)$ ) of each substrate (groundnut waste used in dry and compost form). Five replicates were maintained for each treatment. The experiment was carried out in a polyhouse, where humidity was approximately 55$70 \%$ and temperature $25 \pm 30{ }^{\circ} \mathrm{C}$. The light was provided by cool white fluorescent lamps (8000 lux) under a 16-h photoperiod. The polyhouse received natural sunlight also.

\subsection{Selection of AM fungi, hosts and substrates}

The rhizospheric soil samples of Cymbopogon citratus were examined for a dominant strain of AM fungi i.e. Glomus mosseae and further spores used for the preparation of starter inoculum. The identification of AM spores was done by using the identification manual of Schenck and Perez (1990). Two host plants namely sesame and sorghum (member of Pedaliaceae and Poaceae family respectively) were screened for each substrate. Dry and compost forms of groundnut waste were selected for mass multiplication of G. mosseae. Groundnut waste was collected from the university market, the first sundried, grounded to make fine powder and used as dry form, and for the second form collected waste subjected for further decomposition (placed in jute bags and buried under soil for 3 months). Both forms of substrates were autoclaved at $121{ }^{\circ} \mathrm{C}$ for $2 \mathrm{hr}$ and then utilized in different concentrations with soil: sand (3:1) in pots for mass production of the AM fungi in polyhouse.

\subsection{Preparation of Starter inoculums}

The starter culture of the selected AM fungal spores was multiplied with sorghum as a host using the soil funnel technique of Menge and Timmer (1982). In this technique, earthen funnels (Chillams) were filled with sterilized sand: soil mixture (1:3), inoculated with selected AM spores and then disinfected seeds of sorghum were sown for 30 days. The inoculum thus produced was further subjected for the multiplication of AM fungi first under big earthen pots for 60 days. The inoculum produced in earthen pots was examined for root colonization and spore count by methods suggested by Gerdemann and Nicolson (1963) and Philips and Hayman (1970) respectively, and then used as starter inoculums for further study.

\subsection{Experimental setup}

Top soil for this experiment was collected from Botanical Garden Kurukshetra University, Kurukshetra. Initially, the soil was air-dried, pulverized and then sieved through a $2 \mathrm{~mm}$ sieve. The soil was then mixed with the sand to form a soil: sand ratio 3:1 and further sterilized in an autoclave at 121 ${ }^{\circ} \mathrm{C}$ for two consecutive days at $15 \mathrm{lb}$ pressure for 15 minutes. Different concentrations of each substrate (without substrate- $0,50,75$ and $100 \mathrm{~g} \mathrm{pot}^{-1}$ ) were mixed thoroughly with soil: sand mixture to make a final volume of $1 \mathrm{~kg}$ which was then added to earthen pots $(15 \times 15 \mathrm{~cm})$. To each pot, $10 \%$ i.e. $100 \mathrm{~g}$ of selected AM inoculum consisting of chopped AM colonized root pieces of sorghum along with soil containing 200-250 AM spores $100 \mathrm{~g}^{-1}$ was added. Healthy seeds of sorghum and sesame after surface sterilization with $0.5 \%$ sodium hypochlorite for $10 \mathrm{~min}$ and subsequent washing with double distilled water were sown in each pot above the layer of inoculum further covered with a layer of sterilized soil mixture. Plants were watered regularly to maintain the moisture content of soil and $100 \mathrm{~mL} \mathrm{pot}^{-1}$ of Hoagland's solution (without $\mathrm{KH}_{2} \mathrm{PO}_{4}$ ) were poured into each pot at 15-day intervals.

\subsection{Harvest and analysis}

Plants were manually uprooted after 90 days of planting to measure plant height and root length. The plants were cleaned in running tap water and then separated into roots and shoots to note down their 
fresh weight, placed in an oven to dry at $70{ }^{\circ} \mathrm{C}$ and then weighted for dry weight. The rhizosphere soil and fresh root samples were assessed for mycorrhization.

\subsection{Statistical analysis}

The experimental data were subjected to analysis of variance and means were separated with the least significant difference test using the IBM Statistical Package for Social Sciences [IBM SPSS, ver. 25, Chicago (IL), USA].

\section{Results}

The data analysis related to inoculum productions of $G$. mosseae shows significant variations in AM spore number and root colonization in relation to the type of host, substrate forms and their different concentrations used for mass multiplication. When sorghum was used as a host, the mycorrhization was

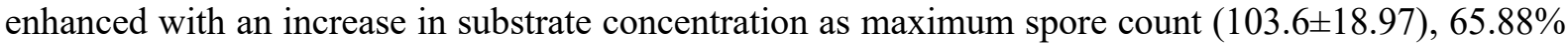
increase in spore number as compared to control and percent root colonization $(66.77 \pm 6.840 \%)$ was recovered with a dry substrate concentration of $100 \mathrm{~g}$ (Table 1). Control plant (without substrate) was reported with the least mycorrhization. However, an increase in concentrations of the dry form of groundnut substrate was also found to be stimulatory in the case of sesame as a host plant and observed maximum spore number $(89.09 \pm 34.91)$ plus percent increase i.e. $(72.36 \%)$ and root colonization $(65.94 \pm 20.31 \%)$ with substrate concentration of $75 \mathrm{~g}$. The least mycorrhization status was observed in the control treatment which had no substrate (Table 3). Similarly, morphological parameters of host plants were also influenced by substrate concentration indirectly through mycorrhization. It was found that the sorghum plants having $100 \mathrm{~g}$ dry groundnut substrate concentration had improved shoot fresh $(03.67 \pm 0.856 \mathrm{~g})$ and dry weight $(1.116 \pm 0.035 \mathrm{~g})$, root length $(19.55 \pm 2.715 \mathrm{~cm})$, root fresh $(2.170 \pm 0.771 \mathrm{~g})$ and dry weight $(1.20 \pm 0.047 \mathrm{~g})$ except shoot height i.e. $(45.83 \pm 06.75 \mathrm{~cm})$ with substrate concentration of $50 \mathrm{~g}$ (Table 2). So, a positive influence of mycorrhization was observed for maximum growth parameters in the sorghum plant. In the case of sesame, plant height $(40.09 \pm 11.53 \mathrm{~cm})$ was recorded highest at $50 \mathrm{~g}$ dry groundnut substrate concentration. Other parameters like shoot fresh weight $(2.336 \pm 0.221 \mathrm{~g})$ dry weight $(1.096 \pm 0.215 \mathrm{~g})$, root length $(14.59 \pm 5.859 \mathrm{~cm})$, root fresh weight $(1.356 \pm 0.357 \mathrm{~g})$ and dry weight $(1.030 \pm 0.105 \mathrm{~g})$ were reached a maximum level at $75 \mathrm{~g}$ dry groundnut substrate concentration (Table 4).

When compost form of groundnut waste was used as substrate and sorghum as the host plant, maximum spore count $(125.1 \pm 30.91)$, as well as AM root colonization $(72.30 \pm 12.80 \%)$ were observed with $75 \mathrm{~g}$ concentration. On comparing spore count and root colonization with the control plant, percent increase was recorded maximum with $75 \mathrm{~g}$ per pot concentration of compost waste When sesame plants were used as hosts with compost groundnut substrate, root colonization $(67.57 \pm 14.00 \%)$ and spore count $(92.76 \pm 12.94)$ were recorded highest at $75 \mathrm{~g}$ concentration of substrate (Table 1). Data analysis studies clearly showed that the root colonization positively influenced the morphological parameters of sorghum like plant height $(55.13 \pm 03.73 \mathrm{~cm})$, shoot fresh $(03.86 \pm 0.630 \mathrm{~g})$ and dry weight $(1.256 \pm 0.659$ $\mathrm{g})$, root length $(25.21 \pm 4.775 \mathrm{~cm})$ and root fresh $(3.466 \pm 1.098 \mathrm{~g})$ and dry weight $(1.36 \pm 0.015 \mathrm{~g})$ (Table 2). Shoot height $(50.26 \pm 3.689 \mathrm{~cm})$, fresh weight $(4.180 \pm 0.096 \mathrm{~g})$ and dry weight $(1.270 \pm 0.151 \mathrm{~g})$ were recorded maximum at a substrate concentration of $75 \mathrm{~g}$ in the dicot plant as the host. In the same way, root length $(20.86 \pm 2.540 \mathrm{~cm})$, root fresh weight $(1.856 \pm 0.281 \mathrm{~g})$ and dry weight $(1.006 \pm 0.081 \mathrm{~g})$ were reported maximum with $75 \mathrm{~g}$ concentration of compost form of groundnut substrate in sesame as host (Table 4). When sorghum and sesame were used as host with dry and compost form of groundnut substrate at a concentration of $75 \mathrm{~g}$ was found best for mass multiplication of $G$. mosseae.

The data analysis related to inoculum productions of $G$. mosseae shows significant variations in AM spore number and root colonization in relation to the type of host, substrate forms and their different concentrations used for mass multiplication. When sorghum was used as the host, the mycorrhization


percent root colonization $(66.77 \pm 6.840 \%)$ was recovered with a dry substrate concentration of $100 \mathrm{~g}$ (Table 1). Control plant (without substrate) was reported with the least mycorrhization. However, the increase in concentrations of the dry form of groundnut substrate was also found to be stimulatory in the case of sesame as the host plant and observed maximum spore number (89.09 \pm 34.91$)$ and root 
colonization $(65.94 \pm 20.31 \%)$ with substrate concentration of $75 \mathrm{~g}$. The least mycorrhization status was observed in the control treatment which had no substrate (Table 3). Similarly, morphological parameters of host plants were also influenced by substrate concentration indirectly through mycorrhization. It was found that the sorghum plants having $100 \mathrm{~g}$ dry groundnut substrate concentration had improved shoot fresh $(03.67 \pm 0.856 \mathrm{~g})$ and dry weight $(1.116 \pm 0.035 \mathrm{~g})$, root length $(19.55 \pm 2.715 \mathrm{~cm})$, root fresh $(2.170 \pm 0.771 \mathrm{~g})$ and dry weight $(1.20 \pm 0.047 \mathrm{~g})$ except shoot height i.e. $(45.83 \pm 06.75 \mathrm{~cm})$ with substrate concentration of $50 \mathrm{~g}$ (Table 2). So, a positive influence of mycorrhization was observed for maximum growth parameters in sorghum plant. In the case of sesame, plant height $(40.09 \pm 11.53 \mathrm{~cm})$ was recorded highest at $50 \mathrm{~g}$ dry groundnut substrate concentration. Other parameters like shoot fresh weight $(2.336 \pm 0.221 \mathrm{~g})$ dry weight $(1.096 \pm 0.215 \mathrm{~g})$, root length $(14.59 \pm 5.859 \mathrm{~cm})$, root fresh weight $(1.356 \pm 0.357 \mathrm{~g})$ and dry weight $(1.030 \pm 0.105 \mathrm{~g})$ were reached a maximum level at $75 \mathrm{~g}$ dry groundnut substrate concentration (Table 4).

Table 1. Influence of groundnut waste as substrates (dry and compost) and their different concentrations on mycorrhization status associated with host plant (sorghum) used for mass multiplication of G. mosseae

\begin{tabular}{|c|c|c|c|c|c|c|c|c|}
\hline \multirow{2}{*}{$\begin{array}{l}\text { Form of } \\
\text { groundnut } \\
\text { waste as } \\
\text { Substrate }\end{array}$} & \multirow{2}{*}{$\begin{array}{l}\text { Concentration } \\
\text { of substrate } \\
\left(\mathrm{g} \mathrm{pot}^{-1}\right)\end{array}$} & \multirow{2}{*}{$\begin{array}{c}\text { AM spore } \\
\text { number/100 g } \\
\text { of soil }\end{array}$} & \multirow{2}{*}{$\begin{array}{c}\text { Percent } \\
\text { increase } \\
\text { in AM } \\
\text { spore } \\
\text { number }\end{array}$} & \multirow{2}{*}{$\begin{array}{c}\text { AM root } \\
\text { colonization } \\
(\%)\end{array}$} & \multirow{2}{*}{$\begin{array}{c}\text { Percent } \\
\text { increase in root } \\
\text { colonization }\end{array}$} & \multicolumn{3}{|c|}{ Pattern of colonization } \\
\hline & & & & & & Mycelium & Vesicles & Arbuscules \\
\hline \multirow{4}{*}{ Dry } & Control & $35.34 \pm 2.103^{\mathrm{cd}}$ & - & $35.34 \pm 2.101^{\mathrm{bc}}$ & - & + & + & - \\
\hline & 50 & $60.85 \pm 11.31^{\mathrm{bc}}$ & 41.92 & $60.85 \pm 10.34^{\mathrm{a}}$ & 41.92 & + & - & + \\
\hline & 75 & $103.6 \pm 18.97^{\mathrm{a}}$ & 65.88 & $66.37 \pm 5.024^{\mathrm{a}}$ & 46.75 & + & ++ & ++ \\
\hline & 100 & $103.3 \pm 13.97^{\mathrm{a}}$ & 65.78 & $66.27 \pm 6.840^{\mathrm{a}}$ & 46.67 & ++ & + & + \\
\hline \multirow{9}{*}{ Compost } & Control & $44.01 \pm 8.342^{\mathrm{d}}$ & $\begin{array}{ll}-- \\
-\end{array}$ & $22.24 \pm 6.604^{\mathrm{c}}$ & $\begin{array}{ll}-- \\
-\end{array}$ & + & + & - \\
\hline & 50 & $64.51 \pm 1.610^{\mathrm{cd}}$ & 31.77 & $70.97 \pm 26.34^{\mathrm{ab}}$ & 68.66 & + & + & + \\
\hline & 75 & $125.1 \pm 30.91^{\mathrm{ab}}$ & 64.82 & $72.30 \pm 12.80^{\mathrm{a}}$ & 69.10 & + & ++ & + \\
\hline & 100 & $109.6 \pm 28.24^{\mathrm{ab}}$ & 59.84 & $70.10 \pm 11.41^{\mathrm{a}}$ & 68.27 & +++ & + & + \\
\hline & L.S.D $(P \leq 0.05)$ & 30.682 & & 21.518 & & & & \\
\hline & ANOVA F $(7,16)$ & 9.153 & & 4.703 & & & & \\
\hline & Substrate type & 5.071 & & 2.599 & & & & \\
\hline & Substrate conc. & 19.505 & & 9.710 & & & & \\
\hline & S type $\times$ S conc & 0.163 & & 0.398 & & & & \\
\hline
\end{tabular}

Each value is mean of five replicates, \pm : standard deviation, S: substrate, AM: Arbuscular mycorrhizae, $-:$ absent, $+:$ scanty, $++:$ moderate, +++ : abundant, means followed by same letter/s within a column are not significantly at $\mathrm{P} \leq 0.05$ level (least significant difference test).

When compost form of groundnut waste was used as substrate and sorghum as the host plant, maximum spore count $(125.1 \pm 30.91)$, as well as AM root colonization $(72.30 \pm 12.80 \%)$ were observed with $75 \mathrm{~g}$ concentration. When sesame plants were used as hosts with compost groundnut substrate, root colonization $(67.57 \pm 14.00 \%)$ and spore count $(92.76 \pm 12.94)$ were recorded highest at $75 \mathrm{~g}$ concentration of substrate (Table 1 and 3). Data analysis studies clearly showed that the root colonization positively influenced the morphological parameters of sorghum like plant height $(55.13 \pm 03.73 \mathrm{~cm})$, shoot fresh $(03.86 \pm 0.630 \mathrm{~g})$ and dry weight $(1.256 \pm 0.659 \mathrm{~g})$, root length $(25.21 \pm 4.775 \mathrm{~cm})$ and root fresh $(3.466 \pm 1.098 \mathrm{~g})$ and dry weight $(1.36 \pm 0.015 \mathrm{~g})$ (Table 2$)$. Shoot height $(50.26 \pm 3.689 \mathrm{~cm})$, fresh weight $(4.180 \pm 0.096 \mathrm{~g})$ and dry weight $(1.270 \pm 0.151 \mathrm{~g})$ were recorded maximum at a substrate concentration of $75 \mathrm{~g}$ in the dicot plant as the host. In the same way, root length $(20.86 \pm 2.540 \mathrm{~cm})$, root fresh weight $(1.856 \pm 0.281 \mathrm{~g})$ and dry weight $(1.006 \pm 0.081 \mathrm{~g})$ were reported maximum with $75 \mathrm{~g}$ concentration of compost form of groundnut substrate in sesame as host (Table 4). When sorghum and sesame were used as the host with dry and compost form of groundnut substrate at a concentration of $75 \mathrm{~g}$ was found best for mass multiplication of G. mosseae. 
Table 2. Influence of groundnut waste as substrates (dry and compost) and their different concentrations on growth parameters of the host plant (sorghum) used for mass multiplication of G. mosseae

\begin{tabular}{|c|c|c|c|c|c|c|c|}
\hline \multirow{2}{*}{$\begin{array}{l}\text { Form of } \\
\text { groundnut } \\
\text { waste as } \\
\text { Substrate }\end{array}$} & \multirow{2}{*}{$\begin{array}{l}\text { Concentration } \\
\text { of substrate } \\
\left(\mathrm{g} \mathrm{pot}^{-1}\right)\end{array}$} & \multirow{2}{*}{$\begin{array}{l}\text { Plant Height } \\
(\mathrm{cm})\end{array}$} & \multicolumn{2}{|c|}{ Shoot weight (g) } & \multirow{2}{*}{$\begin{array}{l}\text { Root Length } \\
\quad(\mathrm{cm})\end{array}$} & \multicolumn{2}{|c|}{ Root weight (g) } \\
\hline & & & Fresh & Dry & & Fresh & Dry \\
\hline \multirow{4}{*}{ Dry } & Control & $31.36 \pm 05.44^{\mathrm{d}}$ & $02.30 \pm 1.093^{\mathrm{bc}}$ & $0.690 \pm 0.336^{\mathrm{a}}$ & $11.93 \pm 2.481^{b c}$ & $1.020 \pm 0.070^{\mathrm{d}}$ & $0.71 \pm 0.347^{b}$ \\
\hline & 50 & $45.83 \pm 06.75^{\mathrm{bcd}}$ & $02.86 \pm 0.546^{\mathrm{abc}}$ & $0.933 \pm 0.085^{\mathrm{a}}$ & $13.74 \pm 2.014^{\mathrm{bc}}$ & $1.133 \pm 0.159^{\mathrm{cd}}$ & $0.97 \pm 0.052^{\mathrm{ab}}$ \\
\hline & 75 & $39.44 \pm 09.21^{\mathrm{cd}}$ & $03.04 \pm 0.605^{\mathrm{abc}}$ & $1.016 \pm 0.070^{\mathrm{a}}$ & $14.33 \pm 0.813^{\mathrm{b}}$ & $1.340 \pm 0.357^{\mathrm{cd}}$ & $1.09 \pm 0.128^{\mathrm{a}}$ \\
\hline & 100 & $42.35 \pm 14.84^{\text {cd }}$ & $03.67 \pm 0.856^{\mathrm{ab}}$ & $1.116 \pm 0.035^{\mathrm{a}}$ & $19.55 \pm 2.715^{\mathrm{a}}$ & $2.170 \pm 0.771^{\mathrm{bc}}$ & $1.20 \pm 0.047^{\mathrm{a}}$ \\
\hline \multirow{9}{*}{ Compost } & Control & $25.22 \pm 02.31^{\mathrm{d}}$ & $02.21 \pm 1.037^{\mathrm{c}}$ & $0.816 \pm 0.515^{\mathrm{a}}$ & $6.686 \pm 3.18^{c}$ & $1.066 \pm 0.654^{\mathrm{d}}$ & $0.26 \pm 0.045^{\mathrm{c}}$ \\
\hline & 50 & $42.49 \pm 12.38^{\mathrm{abc}}$ & $02.28 \pm 0.088^{\mathrm{abc}}$ & $1.032 \pm 0.660^{\mathrm{a}}$ & $18.43 \pm 2.068^{\mathrm{a}}$ & $2.356 \pm 0.453^{\mathrm{ab}}$ & $0.77 \pm 0.163^{\mathrm{ab}}$ \\
\hline & 75 & $50.43 \pm 06.44^{\mathrm{ab}}$ & $03.86 \pm 0.630^{\mathrm{a}}$ & $1.256 \pm 0.659^{\mathrm{a}}$ & $25.21 \pm 4.775^{\mathrm{a}}$ & $3.466 \pm 1.098^{\mathrm{a}}$ & $1.36 \pm 0.015^{\mathrm{ab}}$ \\
\hline & 100 & $55.13 \pm 03.73^{\mathrm{a}}$ & $03.06 \pm 0.895^{\mathrm{abc}}$ & $1.120 \pm 0.617^{\mathrm{a}}$ & $11.69 \pm 2.938^{\mathrm{bc}}$ & $2.096 \pm 0.330^{\mathrm{ab}}$ & $0.63 \pm 0.295^{\mathrm{ab}}$ \\
\hline & L.S.D $(\mathrm{P} \leq 0.05)$ & 14.926 & 1.351 & 0.093 & 4.898 & 1.006 & 0.311 \\
\hline & ANOVA F $(7,16)$ & 5.799 & 2.140 & 0.514 & 6.946 & 6.162 & 6.471 \\
\hline & Substrate type & 15.083 & 0.547 & 0.493 & 0.559 & 13.754 & 5.251 \\
\hline & Substrate conc. & 6.609 & 4.608 & 1.027 & 13.358 & 8.351 & 12.400 \\
\hline & S type $\times S$ conc & 1.894 & 0.202 & 0.008 & 2.662 & 1.443 & 0.949 \\
\hline
\end{tabular}

Each value is mean of five replicates, \pm : standard deviation, $\mathrm{S}$ : substrate, AM: Arbuscular mycorrhizae, means followed by same letter/s within a column are not significantly different at $\mathrm{P} \leq 0.05$ (least significant difference test).

Table 3. Influence of groundnut waste as substrates (dry and compost) and their different concentrations on mycorrhization status associated with host plant (sesame) used for mass multiplication of $G$. mosseae

\begin{tabular}{|c|c|c|c|c|c|c|c|c|}
\hline \multirow{2}{*}{$\begin{array}{l}\text { Form of } \\
\text { groundnut } \\
\text { waste as } \\
\text { Substrate }\end{array}$} & $\begin{array}{l}\text { Concentration } \\
\text { of substrate }\end{array}$ & $\begin{array}{c}\text { AM spore } \\
\text { number/100g }\end{array}$ & $\begin{array}{l}\text { Percent } \\
\text { increase }\end{array}$ & $\begin{array}{l}\text { AM root } \\
\text { colonization }\end{array}$ & $\begin{array}{c}\text { Percent } \\
\text { increase in }\end{array}$ & \multicolumn{3}{|c|}{ Pattern of colonization } \\
\hline & & & number & & & Mycelium & Vesicles & Arbuscules \\
\hline \multirow{4}{*}{ Dry } & Control & $24.62 \pm 11.01^{\mathrm{d}}$ & - & $40.73 \pm 15.66^{\mathrm{abc}}$ & - & + & - & + \\
\hline & 50 & $53.52 \pm 22.40^{\mathrm{bcd}}$ & 53.99 & $52.45 \pm 13.73^{\mathrm{ab}}$ & 22.34 & + & + & + \\
\hline & 75 & $89.09 \pm 34.91^{\mathrm{a}}$ & 72.36 & $65.94 \pm 20.31^{\mathrm{a}}$ & 38.23 & + & - & - \\
\hline & 100 & $70.96 \pm 12.50^{\mathrm{ab}}$ & 65.30 & $54.01 \pm 13.42^{\mathrm{ab}}$ & 24.58 & + & + & + \\
\hline \multirow{9}{*}{ Compost } & Control & $37.11 \pm 7.010^{\mathrm{cd}}$ & - & $43.99 \pm 16.61^{\mathrm{c}}$ & - & + & + & + \\
\hline & 50 & $56.02 \pm 10.50^{\text {bcd }}$ & 33.75 & $55.89 \pm 1.879^{\mathrm{bc}}$ & 21.29 & + & + & - \\
\hline & 75 & $92.76 \pm 12.94^{\mathrm{abc}}$ & 59.99 & $67.57 \pm 14.00^{\mathrm{ab}}$ & 34.89 & + & + & + \\
\hline & 100 & $71.04 \pm 13.92^{\mathrm{abc}}$ & 47.76 & $58.07 \pm 10.87^{\mathrm{ab}}$ & 24.24 & + & + & + \\
\hline & L.S.D $(\mathrm{P} \leq 0.05)$ & 30.723 & & 23.187 & & & & \\
\hline & ANOVA F $(7,16)$ & 4.099 & & 3.097 & & & & \\
\hline & Substrate type & 0.820 & & 3.431 & & & & \\
\hline & Substrate conc. & 8.513 & & 5.488 & & & & \\
\hline & S type $\times S$ conc & 0.780 & & 0.595 & & & & \\
\hline
\end{tabular}

Each value is mean of five replicates, \pm : standard deviation, S: substrate, AM: Arbuscular mycorrhizae, -: absent, +: scanty, ++: moderate, +++ : abundant, means followed by the same letter/s within a column are not significantly different at $\mathrm{P} \leq 0.05$ level (least significant difference test). 
Table 4. Influence of groundnut waste as substrates (dry and compost) and their different concentrations on growth parameters of host plant (sesame) used for mass multiplication of G. mosseae

\begin{tabular}{|c|c|c|c|c|c|c|c|}
\hline \multirow{2}{*}{$\begin{array}{l}\text { Form of } \\
\text { groundnut } \\
\text { waste as } \\
\text { substrate }\end{array}$} & \multirow{2}{*}{$\begin{array}{l}\text { Concentration } \\
\text { of substrate }(\mathrm{g} \\
\left.\text { pot }^{-1}\right)\end{array}$} & \multirow{2}{*}{$\begin{array}{l}\text { Plant Height } \\
(\mathrm{cm})\end{array}$} & \multicolumn{2}{|l|}{ Shoot weight (g) } & \multirow{2}{*}{$\begin{array}{l}\text { Root Length } \\
(\mathrm{cm})\end{array}$} & \multicolumn{2}{|c|}{ Root weight (g) } \\
\hline & & & Fresh & Dry & & Fresh & Dry \\
\hline \multirow{4}{*}{ Dry } & Control & $14.82 \pm 3.436^{\mathrm{c}}$ & $0.980 \pm 0.776^{\mathrm{c}}$ & $0.483 \pm 0.176^{\mathrm{c}}$ & $5.333 \pm 0.881^{\mathrm{e}}$ & $0.646 \pm 0.368^{\mathrm{d}}$ & $0.350 \pm 0.026^{\mathrm{c}}$ \\
\hline & 50 & $40.09 \pm 11.53^{\mathrm{a}}$ & $2.190 \pm 0.105^{\mathrm{ab}}$ & $1.046 \pm 0.171^{\mathrm{ab}}$ & $10.93 \pm 1.427^{\mathrm{d}}$ & $1.093 \pm 0.109^{\mathrm{cd}}$ & $0.836 \pm 0.050^{\mathrm{ab}}$ \\
\hline & 75 & $36.21 \pm 14.62^{\mathrm{ab}}$ & $2.336 \pm 0.221^{\mathrm{ab}}$ & $1.096 \pm 0.215^{\mathrm{ab}}$ & $14.59 \pm 5.859^{\mathrm{bcd}}$ & $1.356 \pm 0.357^{\mathrm{abc}}$ & $1.030 \pm 0.105^{\mathrm{a}}$ \\
\hline & 100 & $31.73 \pm 4.075^{\mathrm{ab}}$ & $2.090 \pm 0.103^{\mathrm{abc}}$ & $1.030 \pm 0.401^{\mathrm{ab}}$ & $13.81 \pm 2.450^{\mathrm{cd}}$ & $1.216 \pm 0.061^{\mathrm{bc}}$ & $0.963 \pm 0.300^{\mathrm{a}}$ \\
\hline \multirow{9}{*}{ Compost } & Control & $23.19 \pm 1.875^{\mathrm{bc}}$ & $1.250 \pm 0.538^{\mathrm{bc}}$ & $0.446 \pm 0.125^{\mathrm{c}}$ & $4.53 \pm 1.532^{\mathrm{e}}$ & $0.623 \pm 0.188^{\mathrm{d}}$ & $0.373 \pm 0.109^{\mathrm{c}}$ \\
\hline & 50 & $31.11 \pm 3.116^{\mathrm{ab}}$ & $2.156 \pm 1.005^{\mathrm{ab}}$ & $0.740 \pm 0.105^{\mathrm{bc}}$ & $20.23 \pm 1.700^{\mathrm{ab}}$ & $1.383 \pm 0.149^{\mathrm{abc}}$ & $0.679 \pm 0.105^{\mathrm{b}}$ \\
\hline & 75 & $50.26 \pm 3.689^{\mathrm{a}}$ & $4.180 \pm 0.096^{\mathrm{a}}$ & $1.270 \pm 0.151^{\mathrm{a}}$ & $20.86 \pm 2.540^{\mathrm{a}}$ & $1.856 \pm 0.281^{\mathrm{a}}$ & $1.006 \pm 0.081^{\mathrm{ab}}$ \\
\hline & 100 & $37.23 \pm 2.701^{\mathrm{a}}$ & $3.536 \pm 1.041^{\mathrm{ab}}$ & $0.968 \pm 0.055^{\mathrm{ab}}$ & $19.49 \pm 2.020^{\mathrm{abc}}$ & $1.846 \pm 0.550^{\mathrm{ab}}$ & $0.920 \pm 0.135^{\mathrm{ab}}$ \\
\hline & L.S.D $(\mathrm{P} \leq 0.05)$ & 12.385 & 1.072 & 0.347 & 4.698 & 0.520 & 0.240 \\
\hline & ANOVA F $(7,16)$ & 5.535 & 2.901 & 5.035 & 15.222 & 6.935 & 10.801 \\
\hline & Substrate type & 2.957 & 4.982 & 0.426 & 12.179 & 6.757 & 4.268 \\
\hline & Substrate conc. & 9.462 & 4.192 & 10.558 & 27.569 & 12.566 & 23.155 \\
\hline & $\mathrm{S}$ type $\times \mathrm{S}$ conc & 2.468 & 0.918 & 1.050 & 3.890 & 1.363 & 0.624 \\
\hline
\end{tabular}

Each value is mean of five replicates, \pm : standard deviation, $\mathrm{S}$ : substrate, AM: Arbuscular mycorrhizae, means followed by same letter/s within a column are not significantly different at $\mathrm{P} \leq 0.05$ level (least significant difference test).

\section{Discussion and Conclusion}

The two host plants used for the experiment are found selective for the mycorrhizal association. Sorghum was reported to be the best host as compared to sesame. The mycorrhization of G. mosseae was recorded highest in sorghum host amended with compost form of groundnut waste at the concentration of $75 \mathrm{~g} \mathrm{pot}^{-1}$. Variation in root types, root architecture, nutrient status and hormone production in relation to the rhizospheric environment might be the causative factors behind host susceptibility for mycorrhization (Rajkumar et al., 2012). Moreover, growth conditions like the type of soil, moisture, $\mathrm{pH}$, fertility, temperature and light condition, microbial interaction and ability of plants to acclimatize are also accountable for variation in the degree of root colonization in two hosts (Kumar et al., 2021).

The root colonization is directly controlled by the growth of the roots while, the addition of decomposed substrates increased the nutrient availability and improved porosity of the soil which are favourable conditions for the growth of developing root and thus increased availability to host roots for more sporulation as well as root colonization (Coelho et al., 2014). An increase in spore number and root colonization by AMF with sorghum plant has been reported by Kadian et al. (2018).

The variable responses are also corresponding to the availability of nutrients in used substrates with different hosts. After decomposition, groundnut waste has been reported to contain more nutrients like total nitrogen $2.76 \%$, total potassium $-1.48 \%$, while total phosphorus content $-0.67 \%$, organic carbon $27.1 \%, \mathrm{C} / \mathrm{N}$ ratio 9.8 are reduced than the unused form of organic wastes (Torkashvand et al., 2015). Many studies confirmed the positive influence of compost waste as substrates on AMF sporulation (Agnihotri et al., 2021). The application of these organic wastes was found to be stimulatory for sporulation as well as root colonization in both the trap hosts and increased in addition to wastes as compared to the control which consisted of soil sand mixture. The positive impact of substrates on mycorrhization status was supported by increased water holding capacity, soil aeration, nutrient uptake, space for spreading of roots due to the addition of wastes thus more surface area for colonization and nutrient absorption (Kadian et al., 2019). Moreover, the availability of high nitrogen and low phosphorus content has been observed to promote symbiosis (Ingraffia et al., 2021). On the other hand, the soil mixture deficient in nitrogen promotes competition among the host plants and the fungi for nitrogen. This affects the mycorrhizal sporulation as well as root colonization in a negative way. The mycorrhizal fungi led to improved phosphorus content of inoculated plants under adequate levels of nitrogen in the soil (Puschel et al., 2016; Bawadekji et al., 2016).

With sorghum as host, spore number of $G$. mosseae and root colonization was found highest at $75 \mathrm{~g} \mathrm{pot}^{-1}$ concentration of groundnut waste and lowered at other concentrations. Similarly, the spore 
number of G. mosseae was observed maximum in sesame host supplemented with the same concentration of groundnut waste. This increment in mycorrhization might be due to high cellulose and hemicellulose content in groundnut waste that supports the findings of Tanwar et al. (2013), who also observed that the rate of mycorrhization is directly related to the cellulose content of substrates. In control without substrate, the mycorrhization status was lesser due to decreased aeration and more mechanical stress imposed on roots which favours decreased root colonization (Kadian et al., 2019).

In this mass multiplication experiment, the concentrations of the substrate which tends to increased colonization also observed to increase above plant parts and biomass of host plants because the AM fungi improved the uptake of mineral nutrients and water by increasing the surface area for absorption through the hyphal networks which extend beyond the nutrient-depleted zone of the soil. A similar positive relation between mycorrhization and above plant part biomass of host has been noted by many investigators (Mangla et al., 2012; Sharma et al., 2015; Sharma et al., 2021). Moreover, the occurrence of vesicles and arbuscules in mycorrhizal roots were found to be related to the biomass of the host as the plants had more arbuscules and vesicles in the infected roots had improved morphology and biomass.

\section{References}

Agnihotri, R., Pandey, A., Bharti, A., Chourasiya, D., Maheshwari, H.S., Ramesh, A., Billore, S. D., \& Sharma, M. P. (2021). Soybean processing mill waste plus vermicompost enhances arbuscular mycorrhizal fungus inoculum production. Current Microbiology, 78, 2595-2607.

Bawadekji, A., Al-Barakah, F.N. \& Mridha, A. (2016). New hosts for large scale inoculum production of arbuscular mycorrhizal fungi from Saudi soils. Journal of Applied Environmental and Biological Sciences, 6(9), 111-115.

Coelho, I. R., Pedone-Bonfim, M. V. L., Silva, F. S. B., \& Maia, L. C. (2014). Optimization of the production of mycorrhizal inoculum on substrate with organic fertilizer. Brazilian Journal of Microbiology, 45 (4), 1173-1178.

Eman, A. A., Monem, A. E., Saleh, M. M. S., \& Mostafa, E. A. M. (2008). Minimizing the quantity of mineral nitrogen fertilization grapevine by using humic acid, organic and biofertilizers. Research Journal of Agriculture and Biological Sciences, 4(1), 46-50.

Gerdemann, J. W., \& Nicolson, Y. H. (1963). Spores of mycorrhizae Endogone species extracted from soil by wet sieving and decanting. Transactions of the British Mycological Society, 46, 235 244.

Guzmán, Á. S., Delvasto, A., \& Sánchez, E. V. (2015). Valorization of rice straw waste: an alternative ceramic raw material. Cerâmica, 61, 126-136.

Ingraffia, R., Saia, S., Giovino, G., Badagliaca, G., Giambalvo, D., Martinelli, F., Ruisi, P., \& Frenda, S. A. (2021). Addition of high C:N crop residues to a P-limited substrate constrains the benefits of arbuscular mycorrhizal symbiosis for wheat $\mathrm{P}$ and $\mathrm{N}$ nutrition. Mycorrhiza, doi: 10.1007/s00572-021-01031-8.

Kadian, N., Yadav, K., Jangra, E., \& Aggarwal, A. (2019). Influence of host plant and rice straw as substrate on mass multiplication of arbuscular mycorrhizal fungi for large-scale agricultural application. International Journal of Recycling of Organic Waste in Agriculture, 8, 21-26.

Kadian, N., Yadav, K., \& Aggarwal, A. (2018). Mass multiplication of arbuscular mycorrhizal fungi associated with some leguminous plants: an ecofriendly approach. Indian Journal of Experimental Biology, 56, 258-266.

Kumar, A., Gupta, A., Aggarwal, A., Singh, J. P., \& Parkash, V. (2021). Ethno-medicinal and AMF diversity conservation aspects of some weeds of Himachal Pradesh, India. Journal of Research in Weed Science, 4(1), 43-56.

Kumar, A., Gupta, A., Aggarwal, A., \& Bhargav, V. (2020). Efficacy of bioinoculants on biomass, nutritional status and yield of lemon grass, Cymbopogon citratus (DC.) Stapf. Journal of Spices and Aromatic Crops, 29(1), 59-66.

Mangla, C., Kumar, A., \& Aggarwal, A. (2012). Inoculum production of endophytic mycorrhiza using mustard seed waste as substrate. Journal of New Biological Reports, 1(2), 61-66. 
Menge, J. A., \& Timmer, L. M. (1982). Procedure for inoculation of plants with VAM in the laboratory, greenhouse and field. In: Schenck NC (ed) Methods and Principles of Mycorrhizal Research, American Phytopathological Society, St. Paul, 59-68.

Musekiwa, P., Moyo, L. B., Mamvura, T. A., Danha, G., Simate, G. S., \& Hlabangana, N. (2020). Optimization of pulp production from groundnut shells using chemical pulping at low temperatures. Heliyon, 6, 1-9.

Pacheco, I., Ferreira, R., Correia, P., Carvalho, L., Dias, T., \& Cruz, C. (2021). Microbial consortium increases maize productivity and reduces grain phosphorus concentration under field conditions. Saudi Journal of Biological Sciences, 28(1), 232-237

Phillips, J. M., \& Hayman, D. S. (1970). Improved procedures for clearing roots and staining parasitic and vesicular-arbuscular mycorrhizal fungi for rapid assessment of infection. Transactions of the British Mycological Society, 55, 158-161.

Prasad, P. V. V., Kakani, V. G., \& Upadhyaya, H. D. (2009). Growth and production of Groundnut, In: Verheye, W. H. (ed.), Soils, Plant Growth and Crop Production, Eolss Publishers, Oxford, UK, $1-30$.

Puschel, D., Janouskova, M., Hujslova, M., Slavikova, R., Gryndlerova, H., \& Jansa, J. (2016). Plantfungus competition for nitrogen erases mycorrhizal growth benefits of Andropogon gerardii under limited nitrogen supply. Ecology and Evolution, 6(13), 4332-4346.

Rajkumar, H. G., Seema, H. S. \& Sunil, K. C. P. (2012). Diversity of arbuscular mycorrhizal fungi associated with some medicinal plants in Western Ghats of Karnataka region, India. World journal of science and technology, 2(1), 13-20.

Ramgopal, Y., Chaitanya, V., \& Chowdary, M. (2016). A study on production of pulp from ground nut shells. International Journal of Scientific and Engineering Research, 7(6), 423-428.

Schenck, N. C., \& Perez, Y. (1990). Manual for the identification of VA mycorrhizal (VAM) fungi. University of Florida, Synergistic PubFlorida, USA, 241.

Sharma, N., Kumar, A., \& Aggarwal, A. (2021). Mycorrhizal Fungi and Potassium alleviating water stress imposed during different stages of growth in Phaseolus mungo. Research Journal of Chemistry and Environment, 25(7), 23-33.

Sharma, N., Yadav, K., \& Aggarwal, A. (2017). Role of potassium and arbuscular mycorrhizal fungi in alleviation of water stress on Vigna mungo. Environmental and Experimental Biology, 15, 1524.

Sharma, S., Sharma, S., \& Aggarwal, A. (2015). Screening of different hosts and substrates for inocula production of arbuscular mycorrhizal fungi. Mycorrhiza News, 27(1), 6-12.

Tanwar, A., Aggarwal, A., Yadav, A., \& Parkash, V. (2013). Screening and selection of efficient host and sugarcane bagasse as substrate for mass multiplication of Funneliformis mosseae. Biological Agriculture and Horticulture, 29(2), 107-117.

Torkashvand, A. M., Alidoust, M., \& Khomami, M. A. (2015). The reuse of peanut organic wastes as a growth medium for ornamental plants. International Journal of Recycling Organic Waste in Agriculture, 4, 85-94.

Zheng, W., Phoungthong, K., Lü, F., Shao, L. M., \& He, P.J. (2013). Evaluation of a classification method for biodegradable solid wastes using anaerobic degradation parameters. Waste Management, 33(12), 2632-2640. 